ANA CRISTINA HAMAT

Museum of the Highland Banat

Reșiţa, Romania

E-mail: anahamat@yahoo.com
Received: August 01st 2020

Accepted: December 10th 2020

Original research article

904:725.92"652"(498)

COBISS.SR-ID 29141513

https://doi.org/10.18485/arhe_apn.2020.16.11

\title{
THE EXPLOITATION AND REUSE OF THE ROMAN RUINS FROM TIBISCUM, STARTING FROM THE MEDIEVAL TO THE MODERN AGE
}

\begin{abstract}
This article wishes to discuss the reuse of monuments, construction materials and of other objects from the Roman period discovered at Tibiscum, starting with the Medieval Age and until the Modern Age. The locations with such discoveries are located near the Roman site, at Jupa, Căvăran-Ct. Daicoviciu, Caransebeș, Turnu Ruieni and possibly at Cărbunari- Țigănești and Obreja. In general, the materials that were reused included construction materials, stone, brick and especially fragmentary or complete monuments; small, precious objects such as ancient gems were also reused, being mounted in medieval rings. The vast majority of such spoils was reused in building or rebuilding medieval churches, the medieval keep from Turnu Ruieni or the medieval fortress at Caransebeș. The spoliation of Tibiscum begins for certain from the 14th century and continues in the next one, based on the policy of the Hungarian royalty of building new places of worship and repairing the royal fortresses given the danger represented by the Turkish expansion.

In the Modern Age, the Roman monuments have been used to embellish the houses of the inhabitants from Caransebeș or the manor from Jupa, belonging to the Capra family of nobles. Fortunately, located nowadays in the archaeological reservation from Jupa, Tibiscum is most carefully unearthed and researched. Still, many of the objects unearthed at Tibiscum in the period before the reservation was created remain lost to this day, while many of the monuments plundered from the Roman centre and encased in the walls of modern buildings, no longer exist.
\end{abstract}

\section{KEYWORDS: DACIA, TIBISCUM, ROMAN SPOLIA, MEDIEVALAGE, MODERNAGE, MONUMENTS, JEWELLERY.}

In loving memory of professor Doina Benea

The Roman centre from Tibiscum represents an important point on the map of Roman Dacia, being comprised of the Roman fort and city, both located at the junction of the imperial roads coming from Dierna and Lederata, passed through Tibiscum and led towards the north of the province. The Roman ruins are currently located on the territory of Jupa village - where the Tibiscum archaeological reservation protects them - as well as on the territory of Iaz, both villages are located near the city of Caransebeș.

Our article discusses the plundering of the ruins of Roman Tibiscum and their reuse in the building of several medieval or modern monuments located in its close proximity, especially the building of medieval Caransebeș, as well as the reuse of the objects discovered in the Roman centre, during the Medieval and Modern ages. With regards to the plundering and the reuse of the ruins of Tibiscum, we mention that this topic has been only partially discussed until now, in studies regarding Roman monuments (Crînguș 2001: 91-95; Balaci Crînguș 
2013: 367-371), ancient gems and cameos discovered in medieval contexts (Hamat: 2016, 69-76; Hamat: 2017, 417- 437), medieval monuments (Bona: 1993; Săcară: 2002, 189-192) and even in the context of studies dedicated to archaeologic historiography (Hamat: 2017a, 2015- 2018). Unfortunately, the presence of information in different fields has prevented the creation of a complete picture for the level of plundering endured by the Roman city. In general, when discussing the Romanian historiography, both sides involved, the ancient and the medieval one, have tried to evaluate this type of intervention, especially for what is entitled by the reuse of Roman monuments and building materials or even for the irreversible destruction of the ancient monuments - detected by analysing the medieval mortar, or in the archaeological marks of the medieval or modern lime whorkshops situated in the ancient sites (Rusu 2008: 24- 37). The chemical analyses have highlighted the fact that the medieval mortar contained crushed Roman age tegular materials. Currently, we have bibliographic references for the reuse of ancient monuments from Dacia by overlapping or by looting theirs remains from Romula/ Malva- Reșca (Tătulea: 1994, 9), the termal edifice of Legio VII Cl. from Cioroul Nou (Bondoc: 2015, $29,33,45,59,75)$, roman fort from Slăveni (Tudor, Popilian, Gudea, and Bondoc 2011: 16-17, 26, 29), Drobeta- Drobeta Turnu Severin (Matei 2016: 348), Ad Mediam- Băile Herculane (Steube 2003: 40-44), Berzobis- Berzovia (Țeicu 1996: 38; Medeleț and Flutur 2002; Hamat 2018: 26), Ulpia Traiana Sarmizegetusa- Sarmizegetusa (Marinoiu 2000; Rusu 2008: 24- 37; Nemeti and Nemeti 2011: 436; Băeștean and Albulescu 2012: 12-18; Mărgineanu Cârstoiu 2013), Micia- Vețel (Tutilă 2009; Nemeti and Nemeti 2011: 436- 437; Tutilă and Barbu 2019: 65-71), Aquae- Călan, Germisara- Geoagiu (Nemeti and Nemeti 2011: 436437), Apulum- Alba Iulia (Nemeti and Nemeti 2011: 437; Izdrăilă and Florescu 2012; Ota and Florescu 2016: 205- 234; Matei 2016: 348), Ampelum- Zlatna, Alburnus Maior- Roșia Montană
(Nemeti and Nemeti 2011: 437), Potaissa- Turda (Nemeti and Nemeti 2011: 437; Matei 2016: 348), Cluj- Napoca (Antal and Pupeză 2012: 92-93), Porolissum- Zalău (Deac 2018; Deac and Zăgreanu 2011: 167), roman fort from Certinae - Romita (Nemeti and Nemeti 2011: 437; Piso and Deac 2019: 253-256) and Brâncovenești (Protase 2008: 250), roman settlement from Jebucu (Ardevan and Zăgreanu 2012: 73-84), roman villa from Chinteni (Deac and Zăgreanu 2011: 165- 167), the the settlement from Miercurea Sibiului- La Mălăiești, Apoldu de Jos, the statio from Miercurea Sibiului- Cunța (Urduzia and Pinter 2016: 235- 237) and others. From this examples we can observe a similar situation to what is happening also in the rest of Europe (Jacks 2008; Kinney 2013; Špehar 2019). Included in this list, we consider that Tibiscum also deserves its own discussion concerning the areas with Roman discoveries reused in medieval and modern contexts.

\section{INTRODUCTION}

The Roman city Tibiscum, raised to the rank of municipium by Septimius Severus, is an important military and especially economic centre, located on the south- western border of Roman Dacia (Benea 2013: 158), at the crossroad of imperial roads coming from the southern border of the province, towards its north. Although the city's ruins have attracted the attention of people from the Middle Ages (Hamat 2017a: 206), the systematic archaeologic research has been conducted in the area only from the second decade of the past century and until today, is one of the Roman sites with continuity in terms of research and publication of the discoveries (Benea and Bona 1994; Ardeț and Ardeț 2004; Ardeț 2009; Benea 2011; Benea 2018) and in the last years it has benefitted from research conducted with the help of the newest methods (Pl. I/2).

The ruins from Tibiscum are truly known however starting from the Modern Age. Numer- 
ous scholars or travellers through these lands in between the $16^{\text {th }}$ and $19^{\text {th }}$ century, have noticed in the courtyards of the inhabitants from Jupa and Caransebeș, but also on the fields located between the borders of Jupa, Ciuta and Iaz villages, Roman remains. The first written information about Tibiscum can be found in a manuscript written by Ioan/ Ianos/ Ioannes Mezertius or Mezerzius, canon at Alba Iulia and afterwards archdeacon at the ClujMânăștur Chapter. His notes, from the beginning of the $16^{\text {th }}$ century, contain also references to several Roman inscriptions discovered at Caransebeș, probably originating from Tibiscum (Opriş 1994; Benea and Bona 1994: 9; Rusu and RusuBolindeț 2007: 94- 96). The interest for these ruins is also present in the work of Luigi Fernando Marsigli, an officer in the Austrian army and also eminent scholar (Morărescu and Codrea 2011: 89). He works for the Habsburg Empire and publishes a book about Banat at the beggining of the $18^{\text {th }}$ century, in it mentioning for the first time the location of the ruins of Tibiscum (Marsigli 1726: $67)$. In the second half of the $19^{\text {th }}$ century, Tibiscum is visited by F. Milleker who describes the Roman habitation from both sides of Timiş river (Milleker 1899: 93-94). Ortvay Tivadar (Marsigli 1726: 67; Milleker 1899: 93-97) also located the Roman city in the area of the Jupa, Iaz and Obreja villages, at the end of the 19th century. The first field research was conducted by him in 1875, at the behest of Th. Mommsen (Benea and Bona 1994: 10) and in the context of the creation of a Banat Historical Society, located at Timișoara. The systematic research was begun only in the interwar period, when in 1923-1924, the professor G. G. Mateescu from King Ferdinand University, Cluj - present-day Babeș-Bolyai University - and the Greek-Catholic bishop I. Boroş from Lugoj have conducted the first researches, later continued in between 1964-1976 by M. Moga and D. Benea in following period (Benea and Bona 1994; 10-11; Ardeț and Ardeț 2004: 16; Benea 2013: 158; Benea 2018), currently the scientific manager is D. Rancu.
Unfortunately, until 1923-1924 when G.G. Mateescu conducts the first systematic, important, research in the Roman site, the ruins underwent a systematic destruction, a result of search for valuables or just of the plundering of stone, brick or architectural elements. Such destructions are visible for the period of the Middle Ages through the discoveries of architectural spoils or ancient objects in medieval contexts, while for the later period we even have documents detailing the plundering of the site from Jupa - this action is favoured by the fact that until the beginning of the 20th century the ruins were still visible above the ground (Hamat 2017a: 208).

\section{Jupa village and Capra manor}

The first area with discoveries plundered from Tibiscum is the village Jupa, where the archaeologic reservation is located. Jupa is mentioned by documents from 1440 (Teicu 1998: 341-342) and the medieval and modern village is located much further to the west from the contemporary village, at least until the 18th century, as proven by the Austrian cadastral maps1. The contemporary village is located at a distance of 6 kilometres, in a straight line, from Caransebeș. It is certain that the ancient ruins were known and exploited during the Middle Ages, proof of this is given by the habitation traces discovered near the Roman fortification (Benea, Bona 1994: 68). The reason for this presence might be the need for building materials, both for the development of the medieval centre from Caransebeș, starting from the 14th century and especially during the reign of Louis I and then that of Sigismund of Luxembourg, when the entire medieval Banat, as part of the Hungarian kingdom, enjoys an increase in the building projects. This building effervescence is partially the result of the

1 According with the First Military Survey from 17691772, see Mapire, https://mapire.eu/en/map/firstsurvey-banat $/$ ?layers $=137 \&$ bbox $=2457422.076554418 \% 2 \mathrm{C} 5$ $691437.889882898 \% 2 \mathrm{C} 2483200.464343594 \%$ 2C5699081.592711415. 
religious policy conducted by the Hungarian royalty and its conflicts with the Ottoman Empire.

The history of the Capra family of nobles is very important for the study of the antiquities from Jupa. At the end of the 18th century, they build in the village that was moved to its present-day location, an imposing manor (Balaci Crînguș 2013: 368) (Pl. II/1,2). The family's heir, the baron Alexandru Capra (1851- 1889) (FD 1889: 5), a person with a vast culture and a European education, is the one who discovers and harnesses the potential of the ruins located next to his manor, housing the scholars who came to study them and helping the Hungarian National Museum to acquire objects from this area (Barbu 2018: 69-71). Many of the artefacts unearthed by the villagers in search of treasures were bought by the baron and even today they are valuable and even singular discoveries in the archaeologic landscape of this site. A representative of his period, the baron collects with pleasure ancient artefacts, corresponds with the Budapest museum or discusses with the specialists who came to visit the site. Unfortunately, his life comes to an abrupt end, dying without direct heirs and his collection is lost in the tumultuous events at the end of the $19^{\text {th }}$ century.

Only the family mansion remains from this fortune, with a fragment of a funerary stela, looted probably from Tibiscum (Balaci Crînguș 2013: 368.) ( $\mathrm{Pl}$. II/3) and encased on its northern outer wall. The stela can be included in the category of architectonic, aniconic funerary stelae, in fact the only one of all the aniconic stelae of south-western Dacia. It has a clear, triangle shape fronton, with acroteria on both sides. The beginning of the funerary inscription is still visible: $\mathrm{D}$ (is) M(anibus). The stela is fashioned from white-yellowish limestone, other monuments from Tibiscum are fashioned from this material, especially architectural pieces that probably adorned the different buildings from the civil settlement or the Roman fortification (Balaci Crînguș 2013: 368). With regards to the Capra manor, we must also mention the archaeologic tale stating that the basement of the manor is paved with Roman bricks, among them one with the stamp of the legion IV Flavia Felix (Milleker 1899: 93-95; Benea 2018: 137). Unfortunately, the manor was nationalised after 1949 and is undergoing restauration for several years, thus archaeologists could not visit it and the presence of the legion at Tibiscum and the tegula from the manor's basement bearing its stamp, cannot be proved beyond the story.

The plundering of Roman monuments continued in the $19^{\text {th }}$ century, a series of interested travellers discovering in the houses of the peasants from Jupa Roman monuments and certainly artefacts for sale. The monuments gain a mythical aura, even becoming for some peasants, protectors of the houses and the fields or patrons of human luck and fate and so, they prefer to destroy them on the spot, rather than sell them or see them being taken away.

It is in this context that a young priest name Iosif Mircea, comes to Jupa at the beginning of the 20th century. He will serve in the village's church between 1910-1938 (Hamat 2017a). Due to his role of parish priest, he listened to the confessions detailing stories about treasure hunts taking place in the middle of the ruins near the village, which he could still see them standing. He realizes the importance of the area and tries to do everything possible so that they can be preserved for future generations and first of all, researched. And because he is not an archaeologist, decides to do what he knows best, namely write about them and help the people in the area know about them and by using education, to save them from forgetfulness and especially from the ignorance that had as an immediate effect, the treasure hunt. Thus, in the newspaper Foaia Diecezană published on the 10th of May, $18^{\text {th }}$ of October and $25^{\text {th }}$ of October 1922 an article discussing the ruins from Tibiscum was included. The title of the first article Excurzia elevilor Liceului Traian Doda la cetatea Tibiscum (Mircea 1922a: 4) (The trip undertook by the students from Traian Doda High School at Tibiscum fortress), becomes a pretext for a dis- 
course in favour of preserving the Roman ruins, further strengthened by the second title Crâmpeie din zbuciumul trecutului nostru. Cetatea Tibiscum (Mircea 1922b: 5-7; Hamat 2017a: 208) (Fragments from the struggles of our past. Tibiscum fortress). The story starts simply: În hotarul parohiei mele Jupa, încă se află o cetate vestită odinioară, Tibiscum (Mircea 1922a: 4). (A once famous fortress, Tibiscum, still exists on the border of my parish, Jupa). This parish priest details the destiny of the fortress, especially of the remains and the inhabitants of the area, some of them have their names mentioned - such as Constantin Capra many others are anonymous. The name of the area is also mentioned - at the walls (Mircea 1922b: 6), currently the area is still known as at the walls, fortress (Benea 2013: 158). The fortress is believed to have encompassed a large area and the priest mentions that in the crops of the people one can find walls destroyed with dynamite by the inhabitants, so that they can use the land as they want (Mircea 1922a: 4). The archaeologic preserve currently includes a territory of approximately 17 hectares and is organised starting with 1977 (Benea and Bona 1994: 12), following the discoveries that were the result of the systematic research. The reservation is administered by the County Museum of Ethnography and Border Regiment Caransebes (Muzeul Județean de Etnografie și al Regimentului de Graniță Caransebeş). The dangers faced by the ruins from Jupa are mentioned in the descriptions contained in the articles, whether it is the greed of the people, the treachery waters of Timiş river, the modernisation of the area or just the passage of time. Thus, one of the parishioners told the priest that he used stones from the fortress, also mentioning an important detail, namely that the walls he had broken were painted with a dark blue colour (Mircea 1922a: 4). It is interesting that given the systematic research that will later be conducted in the area, there is no mention in the bibliography about the painted plaster walls. I. Mircea wonders whether the walls on the other side of Timis river, at the border of
Iaz village, are part of the same fortress, belong to the civil settlement or to a different fortification (Mircea 1922b: 7). A century later, due to the archaeologic research (Pisz, Tomas, and Hegy 2020), we know that the Roman city spanned on both sides of Timiş river and that the walls mentioned by the priest most likely belonged to the civil settlement, researched by D. Benea and more recently by A. Ardeț.

Beside gold, the people plunder the stone from the walls still visible above the ground at the beginning of the 20th century. Given the ruins from Iaz, we note that I. Mircea probably did not know about Marsigli's writings, who mentions the existence of another fortification on the other bank of Timiş river (Marsigli 1726: fig. XXXV), or those of Ortvay Tivadar, who discusses the Roman ruins covering both banks of Timiş river (Hamat 2017a: 209). The existence of the Roman remains on the other bank of Timiş river was investigated and published by Ortvay Tivadar in 1873 and 1876 (Ortvay 1873: 103- 104; Ortvay 1876: 32-33). Just like his predecessors, the priest mentions the discovery of inscriptions, bricks (with the stamps MID, MAZY), coins, jewels or funerary lions. With regards to one funerary lion, the local folklore mentions that it was discovered at the mill, in fact the area immediate next to the building 1 from Tibiscum - the headless lion. When discussing the tile stamps mentioned by the priest, it is noticeable that MID is a usual discovery at Tibiscum, being restored as M(aurii) I(uniores) D(aciae) by D. Benea and S. Regep (Benea and Regep 2015: 191), while the second stamp was probably incorrectly read, it is probably MASY - M(arcus) SY(rus) (Benea and Regep 2015: 194). The gold rush affected Jupa and represented one of the reasons for its destruction, just like in any other area touched upon by history. It is interesting to note that during the course of time the archaeologic research dug up very few gold objects, among them two gold rings and a pendant fragment (Hamat 2018a). However, the priest was told several stories about the gold found here. Thus, one of the 
men working at the Jupa mill, dug after gold and found a gold coin that the miller sold for a large sum at Vienna. Another peasant who had found a gold ring, sold it to baron Capra for 40 florins. Two individuals found gold also at Iaz. Also, the priest could see the palpable evidence of this gold rush with his own eyes in the village, where an unnamed woman wore a necklace fashioned from gold coins found in the fortress. The fortress however, fiercely guards the vast majority of riches, only the dancing flames of gold can be seen here at night. This information is part of the traditional curse attached to any place touched upon by history, repository of valuable artefacts but also of past suffering, the words about the end of the place are proof of this. This, he says, must have been caused by fire, because those who dug at the fortress discovered charcoal and human and horse bones mixed together (Hamat 2017a: 210-211).

Modernity is the last factor to play a part in destroying the ruins, being mentioned the fact that during the construction of the railroad that currently connects the city of Timișoara to the capital, passing in the immediate vicinity of Jupa village, walls were discovered, walls that had to be destroyed in order for the work to be completed. The location of the Roman fortification is about 600 meters away from the railroad but until now there are no certain mentions about Roman discoveries being made in the area of the CFR depot, besides those recorded by I. Mircea. Thus, modernisation took its toll on Tibiscum, many of the remains becoming lost forever (Hamat 2017a: 211).

\section{Medieval church from Cărbunari- Țigănești}

It is also in this area, from the administrative territory of Jupa village and near the Roman fortification, that the church located at CărbunariȚigănești was researched at the beginning of the 1990s. It was identified as the church of the medieval village Răcoviță, mentioned in the documents at the half of the 15th century and which no longer exists now (Țeicu 2007: 150-151; Teicu 1998: 364). A necropolis was identified around the church. The monument and the cemetery were dated with the help of coin, in the first half of the 14th century (Teicu 2007: 151) - thus we know that the village existed for certain at least 100 years.

The medieval church overlaps a Roman building whose functionality is unknown, located in the proximity of Tibiscum, on the side of the imperial road Dierna - Tibiscum and it is here that Roman materials were discovered, including a coin from Gordian III (Ardeț 1996: 415-422). Although the author mentions that the Roman building was reused in the construction of the medieval on (Ardeț 1996: 416), we consider there is not enough evidence to support this and we are faced rather with just a reuse of the respective area. Therefore, we are not dealing with an intentional reuse of the ruins from ancient Tibiscum.

\section{Medieval church from Căvăran- Ct. Daicoviciu}

The medieval town named Caran is located $16 \mathrm{~km}$ north of Caransebeş and $12 \mathrm{~km}$ from Tibiscum, on the southern bank of the river Timiş and on the main road from Severin fortress to Timișoara, in the area of modern Căvăran village (today named Ct. Daicoviciu). The inhabitants of this small town (called by the documents cives et hospites de Karan) built a church in Cetate/ Săliște point, sometime in the late fourteenth or early fifteenth century, which was excavated by I. Miloia in 1930s (Pl. V/1). The nave, in the form of an elongated hall, had a bell tower in the western part of the space. On the exterior, the church has pairs of support elements arranged on the west side of the nave and at the altar (T,eicu 2007: 111-112). When building the monument, the medieval craftsmen used Roman bricks (P1. $\mathrm{V} / 2$ ), tiles, stone blocks, fragments of mosaic and marble monuments. They use the roman spolia for building the elevation of the church, to pave the 
interior, and also in the manufacture of medieval mortar (Daicoviciu and Miloia 1930: 15; Miloia 1930: 47-48; Miloia 1931: 36-37). Therefore, we are dealing with an intentional reuse of the ruins from ancient Tibiscum.

\section{The modern town of Caransebeș and the church of the Franciscan monastery}

Caransebeș is the most important area where the ancient spoils were used. The city is located at the confluence of Timiș and Sebeș rivers, in the southeast of the Roman Tibiscum, being mentioned in documents since 1290 (Țeicu 1998: 309), under the name Sebeș and in 1325 as a royal fortress (Țeicu 2009: 108-109). In fact, Jupa is currently just one of its neighbourhoods.

On the current territory of the city were also discovered the ruins of a villa rustica in Măhală point and those of a temple in Câmpul lui Corneanu point (Petrovszky 1975: 367; Petrovszky and Petrovszky 1977). Besides these ruins, various inscriptions were, in the second half of the nineteenth century, embedded in several houses in Caransebeș (Ortvay 1873: 103-104). The plundering of the Roman ruins by the inhabitants of the medieval fortress of Caransebeș (Bona 1993: 70) and later on, those of the modern city, was probably something usual and not a singular event, which span in time from medieval to modern times, and included from bricks and monuments up to small objects, such as is the case of the artefacts discovered in one the city's necropolis, to be discussed below.

Based on the information we have at our disposal so far, we can date the massive plundering from the beginning of the Angevine dynasty and intensifies during the reign of Sigismund of Luxembourg. This period marks an important step in the urbanisation of the medieval centre from Caransebeș. Therefore, between the middle of the 14 th century and the $15^{\text {th }}$ century, the medieval fortress underwent a series of changes, one of the most important being the relocation of the small local nobility, which will move to the newly created city to live following the western model, including the use of ancient gems and cameos. In general, as it is shown by the medieval sources but also by the more recent testimonies, as well as the local archaeological research, the Roman city and fortification were systematically plundered of everything that could be capitalized, and the fact that the ruins remained visible above the ground until the beginning of the last century turned them into a sure target for all those interested (Hamat 2017: 429-430).

The most important point, so far, on the map of the Roman spoils, is the church of the Franciscan monastery from Caransebeș (Pl. III/3), where many reused Roman elements were discovered (Hamat 2016) (Pl. IV). But, let us not forget, that the case of the medieval church is not a singular one, the whole town benefits during the Middle Ages from the construction materials originating from the ruins. Thus, the locals knew that at the edge of the settlement, there was marble, which they systematically robbed to build what was necessary (Mircea 1922b: 7) and it was used either as construction material for houses or it was burned in order to make lime, a practice that spread from the Middle Ages onwards and is known to have been done in several well-known archaeologic dig sites such as Apulum or Ulpia Traiana.

The ruins of the Franciscan monastery in Caransebeș were discovered in 1988, during the demolition works of the buildings located in the centre of the city, to make way for blocks of flats. The importance of this location is proven by the Medieval documents, which mention several Franciscan headquarters in the Banat area (Severin, Orşova, Caransebeș, Chery, Cuiești- Bocșa, Armeniș, Haram and Cuvin), half of which were created with the support of King Louis I (T,eicu 2007: 1), due to his confessional policies, which include also the Caransebeș monument (Țeicu 2007: 59). With the Ottoman expansion taking place in the Balkans, it seems that these headquarters suffered, together with the whole Banat area, 
great destructions at the beginning of the 15th century, following the raids. Thus, the Franciscans demand support from Pope Eugene IV in December 1437 in order to rebuild the churches that were affected. It is now that the third group is created, comprised of laymen that follow the order's spiritual precepts and life style; this group included, besides the king and queen of Hungary, the nobles from Caransebeș Iacob of Măcicaș and his wife, Ioan of Mâtnic and his wife as well as Mihai of Mâtnic (T,eicu 2007: 18). This aspect is extremely important because it is testimony for the existence of a local catholic nobility, included in the third group and whose probable resting place might be in one of the crypts from the Caransebeș church (Țeicu 2007: 59), adorned with Roman gems.

The Franciscan monastery is currently located in the area delimited to the N-NE by the M. Halici street, to the $\mathrm{E}$ by Ardealului street, to the $\mathrm{V}$ by S. Herce street and to the $\mathrm{S}$ by the Revolution Square, in the centre of the city and 6 kilometres away from Tibiscum. A church with the crypts located inside was discovered in this area, as well as the necropolis around it, alongside the remains of a perimeter wall (Bona 1993: Pl. 2-3.). When discussing the dating, we have to say that the $13^{\text {th }}$ century was proposed for the first phase of the church (Bona 1993: 68), however, other researchers put forward as certain a later date, based on documents ${ }^{2}$. The church has a single nave, its walls are supported by buttresses and the entrance is located on the western side. It houses 11 crypts beneath the floors, alongside other funerals separated in the first third of the church, near the entrance. The authors of the discovery state that the monastery ceases its existence at the half of the $16^{\text {th }}$ century (T,eicu 2007: 59). It is probable that the total destruction happened only after the Austrian rule was imposed, when the whole area was rebuilt after the Ottoman- Habsburg wars from the $16^{\text {th }}-18^{\text {th }}$ centuries.

When the church and its crypts were built in Caransebeș, among other funerary objects, four

2 The Franciscan monastery is mentioned in documents from the 14th until 15th centuries, see Țeicu 2007, 58. intaglios (Pl. VII/ 2, 3, 4, 5), between them three gems and a cameo, were discovered alongside bricks and chiselled stones, as well as fragments from monuments from Tibiscum. Two of the gems were republished 10 years later by $\mathrm{C}$. Timoc (Timoc 1998: 115-116), again in 2004 three of them were published by M. Vasile and in 2009 all four were discussed by D. T,eicu (Vasile 2004: 2-3; Țeicu 2009a: 253). Unfortunately, M. Vasile considers the rings to be Roman. The four gems however are mounted in medieval rings and thus we are clearly dealing with an example of how the inhabitants of Caransebeș reused jewels in the $15^{\text {th }}-16^{\text {th }}$ centuries.

Different Roman materials (marble pieces, construction elements, fragments from funerary and honorific monuments, bricks, tiles and others) (Bona 1993: 68- 70) were preserved in the ruins of the church. They were most probably plundered from Tibiscum ${ }^{3}$. Thus, both the foundation and the elevation of the walls contain chiselled stones probably initially in the walls of the Tibiscum Roman fort, as well as bricks used in building the buttresses (Bona 1993: 69). The most important discoveries however are the fragments of Roman monuments discovered encased in the walls of the church (Bona 1993: 69), in the buttresses, around the altar and in the stairs. The most interesting are half a Roman gable depicting Hercules catching the erymanthian wild boar ( $\mathrm{Pl}$. III/2) as well as a fragment from a funerary stela. The gable might originate from a temple or a sacellum, as yet undiscovered in the field. The funerary monument fragment comes from a large stela, fashioned from marble, very damaged (Crînguș 2001: 91-92). Besides them, it is worth mentioning the marble fragments discovered in the altar; they come from an honorary inscription, the dedicant being an augustalis from the Colonia Ulpia Traiana Sarmizegetusa, the artefact is dated in the 2 nd century (Bona 1993; 70).

3 All kind of materials and also objects obtain by despoliation are commonly named by the specialists spolia, see Kinney 2006, 234. 
The crypt number 6 housed 11 graves containing 13 deceased (Bona 1993: 75-78) and includes in its building materials, roman bricks alongside hypocaust tiles (Bona 1993: 66). When it was discovered, M6 was considered to be a woman's grave. The deceased has her hands on her chest and on her left finger a ring with a sardonyx cameo engraved with the image of a child's head (Hamat 2017: 421). The piece is the only inventory object mentioned by the researchers who note that it is an ancient cameo (Bona 1993: 76), which can be dated based on the analogies from the 2 nd century AD. (Hamat 2016: 71).

Crypt 4 housed 6 graves containing 10 skulls, dated based on the inventory in the $14^{\text {th }}-16^{\text {th }}$ centuries (Bona 1993: 72-73). M3 contained a complete skeleton, positioned on its back, with the hands on its chest. The inventory consisted of a gold ring with an ancient gem with the image of a satyr engraved on it (Bona 1993: 72; Hamat 2017: 421).

Crypt 5 housed 8 graves containing 12 skulls, being dated in the $14^{\text {th }}-15^{\text {th }}$ centuries (Bona 1993: 73-75). It was paved with 80 Roman brick fragments, some of them bearing stamps (MID, MASY, ARF and CIV) (Bona 1993: 69), stamps also encountered at Tibiscum (Benea and Regep 2015). Two of the roman gems were discovered in this crypt. M5 contained a completely preserved skeleton, positioned on its back, with the hands resting on the chest and on her left ring finger was a ring with an ancient carnelian gem engraved with Apollo's image (Hamat 2017: 421). M7 contains the skeleton of a man, very well preserved, positioned on his back with the hands resting on his chest; he has in the area of this torso a ring, probably fallen off his hand, a ring with a carnelian gem engraved with the face of a man. The funerary inventory contained besides the ring a silver coin from Sigismund de Luxembourg and two iron horseshoes from the heels of the boots.

One of the important areas containing discoveries is also represented by the medieval fortress of Caransebeș. The fortress is currently located on one of the hills, somehow flanked by the streets
Grădinilor, Potocului, Decebal and Muntele Mic, being almost entirely destroyed by the contemporary destructions. Fragments from a funerary stela were discovered in 1872 in the fortress's perimeter, on Potoc street. Such a discovery was witnessed by K. Torma in 1880 in the walls of the house number 410 , situated very near of the Franciscan church. It seems that the owners of the house 410 had encased four inscriptions in the walls and has sent several Roman monuments to the Austrian general Stanojlovic - other inhabitants from the city proceeded in the same manner. There is a strong possibility that the owner of the modern house 410, found the Roman monuments on his property, which was located on the ruins of the Franciscan monastery and did not rob them directly from Tibiscum, at least not all of them. In this case we would be dealing with a modern reuse of the medieval spolia.

Stones with roman inscriptions might be encased in the wall of the Roman-Catholic church, build in the 19th century on the site of an older church in the centre of the present-day city and near the Franciscan monastery. Unfortunately, they are lost today and the transcript of their inscription as made by $\mathrm{K}$. Torma is also lost. Another epigraph, a votive text dedicated to Apollo and Diana, was encased in the walls of house 9, on Retezat street. The tiles with the stamp of the XIII Gemina legion was discovered when the ground was dug up for the foundation of a house, on Episcopiei street, in the centre of Caransebeș, also at the end of the $19^{\text {th }}$ century (IDR III/1: 142-144).

\section{Medieval church from Obreja}

Another Roman plunder was located nearby Obreja, approximately 6 kilometres from Tibiscum. The late archaeologist D. Țeicu researched a church located in the area known as Sat Bătrân, on the border of the current village. The edifice was dated at the beginning of the $15^{\text {th }}$ century. Around the church is a necropolis with burials dated in 
two distinct periods and with a modest funerary inventory (Țeicu 2009: 109; Hamat 2018: 27). A Roman jasper gem was discovered here, bearing the image of Minerva Nikephoros (Hamat 2016: 422; Hamat 2017: 423; Hamat 2018: 27) (Pl. VII/1). Unfortunately, the exact place of discovery of the gem is not known, the inventory register of the Museum of the Highland Banat from Reșița mentions only the fact that it was discovered inside the church (Hamat 2016: 422). In this case, as in the case from Cărbunari-Țigănești, we cannot say exactly if the gem is reused, in the absence of the exact context of the discovery.

\section{The medieval keep from Turnu Ruieni.}

One of the most beautiful medieval monuments from the area, the keep from Turnu Ruieni $(\mathrm{Pl} . \mathrm{VI})$, is located in the immediate vicinity, 10 kilometres away from Caransebeș, on the road towards Muntele Mic. The keep is positioned on the Stârminița hill, the ruins being almost 10 metres in height. Blocks of marble probably coming from a Roman monument were encased during the construction of the walls (IDR III/1: 141; Miloia 1930: 47; Săcară 1975: 306-307; Săcară 2002: 190), also Roman tegular materials was used for straightening the walls. The keep is mentioned in the documents from the middle of the 15th century as belonging to the Romanian noble family from Mâtnic. But the historians agree that it must have been the result of the Angevin policy and initially a royal possession (Țeicu 2009: 50-51).

An inscription was still visible on one of the blocks in the $19^{\text {th }}$ century, now the inscription cannot be observed anymore. The inscription was discussed by those who still saw it at the end of the $19^{\text {th }}$ century and the beginning of the next one. The text, with only several letters still visible ... OVI... were noted down and it is because of this that the tower was named Ovid's Tower, being connected with the name of the famous poet who died at Tomis and who is placed in the area by the local legend. We consider that this Roman inscription also originates from Tibiscum, based on the proximity of the discovery to the Roman centre (IDR III/1: 141).

\section{CONCLUSION}

To conclude, the territory of ancient Tibiscum and the Roman ruins are known and exploited during the Medieval Age, with evidence of their reuse at Caransebeș, Ct. Daicoviciu, Turnu Ruieni and possibly to Obreja and Cărbunari- Țigănești, for the period of the $14^{\text {th }}-15^{\text {th }}$ centuries. The first evidence for the reuse of roman spolia dates back to the 10th-12th centuries and comes from the archaeologic research of the habitation layers from Tibiscum (Benea and Bona 1994: 68). Let us not forget that at least in between the $7^{\text {th }}-11^{\text {th }}$ centuries, Tibiscum is once again an important settlement, being mentioned in 1018 among the dioceses subordinated to the Ohrida archdiocese with the name Divisiskos- Dibisskos (Benea and Bona 1994: 123).

It is more that certain however, that the exploitation of the ruins begins with the birth of medieval Sebeș, present- day Caransebeș and also for the building purpose in Caran- modern Ct. Daicoviciu. The medieval town Caran and also Sebeș fortress developed at the expense of the territory occupied by the ancient settlement. This is due to the shift in the travel on the ancient road in this area, because of the exclusion of the section in between Tibiscum - Obreja. After Obreja, the road is still widely used until today, as proven by the repairs and the reuse of the Roman bridge from Pons Augusti - located north of Caransebeș, in the Marga- Voislova area, in $15^{\text {th }}$ century (Rusu 1996: 249-252). The modification of the road, through the exclusion of this section, is possibly a consequence of the destruction of the Roman bridge from Tibiscum by Timiş river. The pillars of the Roman bridge survived at least until the $19^{\text {th }}$ century, their ruins were still visible on the terrain, 
now they are destroyed and their location lost. It is certain that in the 14th century the bridge was no longer usable, otherwise it would have been mentioned in the documents, as is the case with the bridge from Pons Augusti. The reuse of the Roman roads and even roman bridges in the Middle Age is also documented in other parts of former Dacia - medieval Transylvania (Toda 2008: 225-241; Cociş, Chiorean and Ciobanu 2018; Chiorean, Cociş and Bere 2019).

It is also important to mention that currently on the territory of Caransebeș there are traces of ancient habitation, in the points Măhală, Orthodox Episcopate-centre and Câmpul lui Corneanu. The area near the medieval fortress, where the ancient settlement is located, is mentioned in 1440 under the name of Tyvisk, in 1447 as Tyws and in 1470 as Tews (Benea and Bona 1994: 123), proof that supports our idea that the ancient settlement was still known and used as a quarry in that period. The fact that the area of the Roman fort and city was no longer inhabited but the ruins were still visible, favoured their being plundered and the reuse of the materials for the construction of the fortress or of medieval churches from the close vicinity, as a direct consequence of the Angevin policy conducted in the area, to strengthen the habitation nuclei existing at the beginning of the $14^{\text {th }}$ century, then to build new Catholic churches aimed at spreading the Catholic faith in the area and last but not least by extending the cities as a base for the noble elites due to the prosperity of the Hungarian Kingdom at the end of the 14th century and for repairing the cities when faced with the Ottoman peril at the beginning of the $15^{\text {th }}$ century.

Along with the development of the city, the importance moved from the noble courts to the house located in the city and the noble families from the area bought estates in Caransebeș. Their members lived mostly here and they were buried in the Catholic churches from the city, such as the church of the Franciscan monastery. Tibiscum offered for this category of population other types of plunder, such as jewels. Only the ancient gems and cameos, mounted in medieval jewellery, have reached us. The gold rush, sometimes led even by the ruling class, is mentioned in the medieval legislation (ACRT: 54, 1) or even the modern one - in 1839 (Stoica 1998: 8). The legislation punishes treasure hunting, which is why the metal jewels discovered in the ruins were probably melted down in order to prevent authorities from taking action and that is why today we only find reused ancient gems and cameos. The reuse of ancient gems and cameos is well documented in Banat and at the court of the Hymfi family from Remetea - near ancient Berzovis ${ }^{4}$, where a noble lady, Iuliana widow of Nicolae Himfy, while at Gyor in the early 15 th century, seals personal letters with an ancient gem (Magina 2017: 355). We also mention the similar case of the gems reused in medieval Hungary (Gesztely and Rácz 2006; Gesztelyi 2011) including Transylvania, in medieval Serbia (Bikić 2016), France (Simonet 2019), Germany (Kinney 2011), Italy ${ }^{5}$, England (Henig 2008: Zwierlein- Diehl 2014: 88), modern Croatia (Kaić 2015) but also in the rest of today's Romania, in the area of Târgu Jiu, Romula or Craiova (Marinoiu and Hamat 2020; Hamat 2017, 430), from the Middle Ages until the modern era. A famous example is the necklace of Maria Severeanu $^{6}$, made in 1922 from gold and 44 gems and cameos, most of them antique.

Like in the rest of the Central Europe, also in Romania, finding of reused Roman gems is most often linked to the proximity of a Roman site (Gesztelyi 2011: 259; Simonet 2019: 361). For medieval people, gemmed seals were advan-

4 The seal in question will be the subject of another study. 5 One of the most famous portrets from the Middle Age is the one of beautiful Simonetta Vespuci, painted by Sandro Boticelli in early- mid 1480, curently found in the collection of Städel Museum - Frankfurt am Main - Germany; Simonetta was painted with a necklace which contains a large antique cameo engraved with the image of both Apollo and Marsyas, see Städel Museum - Frankfurt am Main - Germany, https://sammlung.staedelmuseum.de/en/ work/idealised-portrait-of-a-lady; For this topic see also Tassinari 2019, 43-47.

6 Muzeul Bucureștiului, http://muzeulbucurestiului.ro/ colectia-aur-si-metale-pretioase/ 
tageous in many different ways, from magical, medical, artistic, social, even religious and diplomatic point of view (Simonet 2019: 362; Zwierlein- Diehl 2014), up to the fact that they were much easy to procure. The importance of reused gems for medieval people come also from the situation that these kind of jewelry are part of the economy of prestige goods, which is generally the same from one culture to another. As wealth, they facilitate the distribution and transmission of power and as representations of wealth they maintain or assert power through displaying (Kinney 2011: 105; Sena Chiesa 2011: 229), hence the appearance of the great noble houses collections. Unlike the rest of the Europe, we know that on the territory of Banat region the Roman gems were reused starting with XIV century, for the earlier periods we do not have confirmed information.

In the modern period, with the movement of Jupa village closer to the ruins where its actually located today and being inherited by the Capra family, Tibiscum suffers new destructions, much more important. The monuments from the area being reused in building the manor of the Capra family from Jupa, the Roman-Catholic church from Caransebeș or the houses of private persons from the city or even being shipped to Budapest or Vienna. Unfortunately, the vast majority of such reused monuments were completely lost when the buildings were demolished or are hidden under layers of daub, their memory remains only in the writing from the end of the 19th century.

This is also the period when the ruins located in the area, interest the authorities and especially the researchers that now start the first mappings and field research. Some of the important pieces are now discovered at Tibiscum. Among them we have military diplomas attesting to the presence of the Roman army, epigraphs with the names of civilians, jewellery and other evidence of habitation during the Roman- era. The fact that the Romanian administration took over Banat at the end of World War I, initially intensified the destruction up to an unprecedented level, the people nearby using the stone and bricks for constructions. But, it also meant acknowledging the importance of the ruins for the local and national history. The first attempts at salvaging the ruins are led by the inhabitants of the area, the priests Iosif Mircea from Jupa or Ioan Boroș from Lugoj, the archaeologist Constantin Daicoviciu - from Căvăran, I. Miloia from Timișoara and others. The first systematic research is conducted between 1920-1924 and the archaeologic reservation is created after World War II, the Roman fortification and part of the settlement being now protected.

Today the inhabitants and the local authorities protect the ruins but the danger represented by the treasure hunters has not disappeared, especially with regards to the areas located outside the archaeological reservation. As envisioned by those from the beginning of the 20th century, Tibiscum has developed into a real focus for research and erudition that has long extended outside Romania's borders.

\section{BIBLIOGRAPHY}

\section{ACRT, 1997}

Constitutiile aprobate ale Transilvaniei: (1653), L. Marcu (eds.), Cluj- Napoca: Editura Dacia.

\section{Antal, A. and Pupeză, P. 2012}

Roman finds in the Art Museum Courtyard from Cluj-Napoca, Acta Musei Napocensis, 49/1: 83107.

\section{Ardeț, A. 1996}

Cercetările arheologice la biserica medievală de la Cărbunari-Țigănești (sec. XIII-XIV), Acta Musei Napocensis 33: 415-424.

\section{Ardeț, A. 2009}

Ceramica romană descoperită la Iaz 'Traianu', Cluj- Napoca: Editura Mega. 
Ardeț, A. and Ardeț, L. 2004

Tibiscum. Așezările romane, Cluj-Napoca: Editura Nereamia Napocae.

Ardevan, R. and Zăgreanu, R. 2012

Eine römische inschrift von Jebucu (Sălaj Kreis), Analele Banatului S.N. 20: 73-84.

\section{Barbu, D. 2018}

Armânimea. De la baronul Nicolici de Rudna la boier Capra din Teleorman, Timisiensis, Centrul de cultură și Artă al județului Timiş: 65-74.

\section{Băeștean, G. and Albulescu, T. 2012}

Monografie istorico- etnografică a localității Sarmizegetusa, Deva: Editura Gligor Haşa.

\section{Benea, D. 2011}

Atelierele romane de mărgele de la Tibiscum, Timișoara: Editura Excelsior Art.

\section{Benea, D. 2013}

Istoria Banatului în antichitate, Timişoara: Ed. Excelsior Art.

\section{Benea, D. 2018}

Istoria Banatului în antichitate, București: Editura Academiei Române.

\section{Benea, D. and Bona, P. 1994}

Tibiscum, București: Editura Museion.

\section{Benea, D. and Regep, S. 2015}

Ştampilele tegulare romane de la Tibiscum, Analele Banatului S.N 23: 187-205.

\section{Бикић, В. 2016}

Прстење из Бањске: идентификација и уметничко-занатски контекст, Саопштења XLVII: 82-83.

(Bikić, V. 2016

Rings from Banjska: Identification and the Artistic and Craftsmanship Context, Communications XLVII: 82-83.)

\section{Balaci Crînguș, M. 2013}

Un fragment de stelă funerară de la Tibiscum, $A r$ heovest I: 367-371.

Bona, P. 1993

Biserica medievală din Caransebeș, Reșița: Inspectoratul pentru Cultură.

Bondoc, D. 2015

Edificiul termal (Balneum) al Legiunii VII Claudia de la Cioroiul Nou, Craiova: Editura Sitech.

\section{Crînguș, M. 2001}

Noi monumente sculpturale din zona Caransebeş, Bibliotheca Historica et Archaeologica Universitatis Timisiensis IV: 91-95.

Chiorean, P. Cociș, H and Bere, B. 2019 The Secondary Roads of Potaissa. Case Study II: Trial Trench on the Road Segment from Livadă- Valea Agrișului-Iara (Cluj County), Ziridava. Studia Archaeologica 33: 125-136.

\section{Cociș, H., Chiorean, P. and Ciobanu, C. 2018}

The Secondary Roads of Potaissa. Case Study: A new Road Segment from Livadă-Valea Agrișului-Iara (Cluj County), Ziridava. Studia Archaeologica 32: 93-118.

\section{Daicoviciu, Ct. and Miloia, I. 1930}

Cercetări arheologice în Banatul de Sud, Analele Banatului III: 10-22.

Deac, D. and Zăgreanu, R. 2011

Monumente funerare cu reprezentarea lui Iupiter Ammon în Dacia Porolissensis, Acta Musei Porolissensis XXXIII: 161-172.

\section{Gesztelyi, T. 2011}

The re-use and re-interpretation of gemstones in medieval Hungary, in: C. Enthwistle, N. Adams (ed.), Gems of Heaven Recent Research on Engraved Gemstones in Late Antiquity, AD 200-600, Research publication (British Museum), Londra: 
257-262.

FD 1889

Foaia Diecezană, Caransebeș: Tipografia Diecezană.

Gesztely, T. and Rácz, G. 2006

Antik gemmapecsétek a középkori Magyarországon, Debrecen: Kossuth Egyetemi Kiadó.

Hamat, A.C. 2016

O camee de epocă romană descoperită în cadrul cercetării de la mânăstirea franciscană din $\mathrm{Ca}$ ransebeș, Patrimonium Banaticum VI: 69-76.

Hamat, A.C. 2017

Imaginea nemuritoare a frumuseții. Gemele descoperite în aria municpiului roman Tibiscum (jud. Caraș- Severin), Arheovest V/1: 417-437.

\section{Hamat, A.C. 2017a}

Stories about Tibiscum. The research carried out by the priest Iosif Mircea at the Roman ruins from Jupa, C. Szabó, V. Rusu-Bolindeț, G. T. Rustoiu and M. Gligor (eds.), Adalbert Cserni and his contemporarie. The pioneers of archeology in Alba Iulia, Bibliotheca Musei Apulensis XXIX: 205-218.

Hamat, A.C. 2018

Câteva bijuterii de epocă romană din colecţia Muzeului Banatului Montan Reşiţa, Analele Banatului S.N. XXVI: 25 - 34.

Hamat, A.C. 2018a

Golden Jewellery discovered at Tibiscum, I. V. Ferencz, O. Tutilă, N.C. Rișcuță (eds.), Representation, Sings and Symbols. Proceedings of the Symposium on Life and Daily Life, Cluj- Napoca: Editura Mega, 99-108.

\section{Henig, M. 2008}

The re-use and copying ancient intaglios in medieval personal seals, mainly found in England: An aspect of the Renaissance of the twelfth century',
N. Adams, J. Cherry, J. Robinson (eds.), Good Impressions: Image and authority in medieval seals, Londra: The British Museum, 25-34.

\section{IDR}

Inscriptiones Daciae Romanae, Bucureşti-Paris 1975-2001: Editura Academiei.

Izdrăilă, G. and Florescu, C. 2012

Pietre romane refolosite în construcții medievale din situl de la Alba Iulia, Materiale și Cercetări Arheologice S.N. VIII: 87-96.

\section{Jacks, P. 2008}

Restauratio and Reuse: The Afterlife of Roman Ruins, Places 20/1: 10-20.

\section{Kaić, I. 2015}

Intagliji iz zbirke franjevačkog samostana $\mathrm{u}$ Imotskom, in: Sanja Ivčević, Iva Kaić, Tatjana Kolak, Ondina Krnjak, Daria Ložnjak-Dizdar (eds.), Istraživanja u Imotskoj Krajini, Croatian Archaeological Society Editions 29: 41- 58,

\section{Kinney, D. 2006}

The Concept of Spolia, Conrad Rudolph (ed.), $A$ Companion to Medieval Art: Romanesque attd Gothic in Northern Europe, Oxford: Blackwell Pub, 233-52.

\section{Kinney, D. 2011}

Ancient Gems in the Middle Ages: Riches and Ready-mades, Richard Brilliant, Dale Kinney (eds.), Reuse Value Spolia and Appropriation in Art and Architecture from Constantine to Sherrie Levine, Burlington: Ashgate Publishing Company, 97-120.

\section{Kinney, D. 2013}

Spoliation in Medieval Rome, Stefan Altekamp Carmen Marcks-Jacobs Peter Seiler (eds.), Perspektiven der Spolienforschung 1 Spoliierung und Transposition, Topoi Berlin. Studies of the Ancient World 15: 261-286. 


\section{Magina, L. 2017}

In litteris vestris rescribatis. Corespondența privată în banatul secolelor XV-XVII, Banatica XXVII: 348-359.

\section{Mapire}

Mapire, First Military Survey from 1769-1772, (https://mapire.eu/en/map/firstsurvey-banat/?layers $=137 \&$ bbox $=2457422.076554418 \% 2 \mathrm{C} 569$ $1437.889882898 \% 2 \mathrm{C} 2483200.464343594 \%$ 2C5699081.592711415 - access 21.06.2020).

\section{Marinoiu, V. 2000}

Monumentele sculpturale romane de la Ulpia Traiana Sarmizegetusa, la Poiana, județul Gorj, Litua VIII: 35-43.

\section{Marinoiu, V and Hamat, A.C. 2020}

Piese de gliptică romană aflate în colecția Muzeului Județean Gorj Alexandru Ștefulescu, din Târgu Jiu, Banatica 30/1: 229-255.

\section{Marsigli, L.F. 1726}

Danubius Pannonico-Mysicus, 2, Haga - Amsterdam: Comitum, apud P. Gosse, R.C. Alberts, P. de Hondt, Uytwerf \& Changuion.

\section{Matei, D. 2016}

Reutilizarea fostelor castre ale provinciei Dacia în epocile postromane. Probleme ale cercetării, Acta Musei Porolissensis XXXVIII: 343- 356.

Mărgineanu Cârstoiu, M. 2013 'Migrated' Roman Lithic Fragments in the Vicinity of the Capital of Roman Dacia, C. G. Alexandrescu (ed.), Jupiter on Your Side. Gods and Humans in Antiquity in the Lower Danube Area, Bucharest: Masterprint Super Offset, 164-185.

\section{Medeleț, F. and Flutur, A. 2002}

Castrul roman de la Berzovia. Istoricul cercetărilor arheologice, Patrimonium Banaticum 1: 95-100.

\section{Milleker, B. 1899}

Délmagyarország régiségleletei a honfoglalás elötti időkből, II, Temesvár: Csanád-Egyházmegyei Könyvnyomda.

\section{Miloia, I. 1930}

Biserica medievală dela Căvăran, Analele Banatului III, 1930: 26-53.

\section{Miloia, I. 1931}

Căvăranul în Evul Mediu (O rectificare istorică), Analele Banatului IV: 33-57.

\section{Mircea, I. 1922a}

Excurzia elevilor Liceului Traian Doda la cetatea Tibiscum, Foaia Diecezană 43/XXXV: 3-5.

\section{Mircea, I. 1922b}

Crâmpeie din zbuciumul trecutului nostru. Cetatea Tibiscum, Foaia Diecezană 44/XXXV: 5-7.

Morărescu, G.R. and Codrea, V.A. 2011 Informații mineralogice din secolul XVIII privind teritoriul României în opera lui Luigi Ferdinando Marsigli, "Danubius Pannonico Mysicus", Studii şi Comunicări IV: 89-94.

\section{Muzeul Bucureștiului}

Muzeul Municipiului București, (http://muzeulbucurestiului.ro/colectia-aur-si-metale-pretioase/access 21.06. 2020).

\section{Nemeti, I. Nemeti, S. 2011}

In Ecclesia Pro Ara. On roman "wandering stones" from Romanian churches, I. Piso, V. Rusu- Bolindeț, R. Varga, S. Mustaţă, E. BeuDachin and L. Ruscu (eds.) Scripta Classica. Radu Ardevan Sexagenario Dedicata, Cluj- Napoca: Editura Mega, 435-444.

\section{Opriș, I. 1994}

Istoria muzeelor din Romania, București: Editura Mouseion. 


\section{Ortvay, T. 1873}

A magyar tudomanyos Akademia archaeologiai bizottsănak kozlonye, Archaeologiai Ertesito VII: 103-104.

\section{Ortvay, T. 1876}

Tibiscum helyfekvése az írók és térképírók szerint (I), Archeológiai Közlemények 3, 10: 1- 48.

Ota, R. and Florescu, C.T. 2016 Observaţii asupra incintei vestice a castrului roman de la Apulum şi câteva constatări istorice, Apulum LIII: 205-234.

\section{Piso, I. and Deac, D. 2019}

Epigraphica Porolissensia (II), Acta Musei Porolissensis XLI: 253-261.

Pisz, M., Tomas, A. and Hegy, A. 2020 Non- destructive research in the surroundings of the Roman Fort Tibiscum (today Romania), Archaeological Prospection: https://onlinelibrary.wiley. com/ doi/full/10.1002/arp.1767? fbclid=IwAR1VYoOLIKhDas VXMs2dk7gH4eoor5mIUM1iTK1nX4IUGRgB7RA7QQfWP34.

\section{Petrovszky, R. 1975}

Contribuţii la repertoriul arheologic al localităţilor judeţului Caraş-Severin, din paleolitic până în secolul al V-lea î.e.n. (partea II), Banatica 3: 365-378.

Petrovszky, M. and Petrovszky, R. 1977 O construcţie romană descoperită la Caransebeş, Studii și Comunicări Caransebeș 2: 311-320.

\section{Protase, D. 2008}

Comentarii privind refolosirea monumentelor funerare romane în zidurile castrelor auxiliare din Dacia, Bibliotheca Historica et Archaeologica Universitatis Timisiensis X: 249-254.

Rusu, A.A. 1996

Pons Augusti in el Medioevo, in: M. Porumb (ed.), Omagio a Dinu Adamesteanu, Cluj- Napoca: Ed.
Clusium, 249-252.

\section{Rusu, A.A. 2008}

Continuitatea materială antică în Hațeg (epoca prerenascentistă și a renașterii timpurii), Investigări ale culturii materiale medievale din Transilvania, Cluj- Napoca: Editura Mega.

Rusu, A.A and Rusu- Bolindeț, V. 2007 Casa Mezertius, de la Alba Iulia (Arhitectură, unele piese arheologice, identificare și context istoric), Arheologia Medievală VI: 81-110.

\section{Săcară, N. 1975}

Donjonul de la Turnu Ruieni, Banatica III: 303309.

\section{Săcară, N. 2002}

Donjonul de la Turnu Ruieni, Patrimonium Banaticum I: 189-192.

\section{Sena Chiesa, G. 2011}

Myth Revisited: the Re-use of Mythological Cameos and Intaglios in Late Antiquity and the Early Middle Ages, In: C. Entwistle, N. Adams (ed.), Gems of Heaven. Recent Research on Engraved Gemstones in Late Antiquity, c. AD. 200 - 600, British Museum Research Publication, 177, The Trustees of the British Museum, London: British Museum, 229-238.

\section{Simonet, C. 2019}

The (Re-) Use of Ancient Gems and Coins: The Presence of Antiquity in Medieval Sigillography, L. J. Whatley (ed.), A companion to Seals in the Middle Ages, Chapter 14, Leiden/ Boston: Brill, 355-395.

\section{Špehar, P. 2019}

Reocupation of the Late Antique Fortification on the central Balkans during the Early Middle Ages, T. Tkalčec, T. Sekelj Ivančan, S. Krznar and J. Belaj (eds.), Fortification, Defence Systems, Structures and Features in the Past,_Serta Instituti 
Archaeologici 13, Zagreb:_Institute of Archaeology Zagreb, 133- 124.

Steube, J.K. 2003

Nouă ani în Banat (1772-1781), C. Fenesan (ed.), Timişoara: Editura de Vest.

\section{Städel Museum}

Frankfurt am Main - Germany, (https://sammlung.staedelmuseum.de/en/work/idealised-portrait-of-a-lady; - access 21.06.2020).

\section{Stoica, C. 1998}

L 'histoire de la legislation concernant la protection du patrimoine archeologique mobile et immobife, avec accent sur le XIX-eme siècle, Buletinul Comisiei Monumentelor Istorice IX/3-4: 7-11.

\section{Tassinari, G. 2019}

Per una storia della glittica di propaganda: alcune riflessioni. II. Il post-antico, M Bassani, O.S. Carli (eds.), Frammenti dall' antico: pietre, immagini, testi, La rivista di Engramma, 170: 33-65.

\section{Tătulea, C.M. 1994}

Romula. Malva, București: Editura Museion.

\section{Timoc, C. 1998}

Două geme romane descoperite in biserica medievală din Caransebeș, Buletinul Cercurilor Științifice Studențești. Arheologie-Istorie 4: 115-117.

\section{Toda, O. 2008}

Cercetarea drumurilor medievale din Transilvania şi zonele învecinate: abordări metodologice, $A r$ heologia Medievală VII: 225-241.

Tudor, D., Popilian Gh., Gudea, N. and D. Bondoc 2011

Castrul roman de la Slăveni, N. Gudea, C. Cosma, A. Rustoiu (eds.), Interferențe Etnice și Culturale in mileniile I a. Chr- I. p. Chr, 19, Cluj- Napoca: Editura Mega.
Tutilă, O.C. and Barbu, M. 2019 Monumente funerare romane descoperite la Vețel, jud. Hunedoara, Sargeția SN X (XLVI): 63-75.

\section{Tutilă, O.C. 2009}

Leii funerari romani de la Brănișca, Comunicări Ştiințifice Mediaş VIII: 43-45.

\section{Ţeicu, D. 1996}

Cercetări de arheologie medievală la Berzovia, Arheologia Satului Medieval din Banat, Resita: Muzeul de istorie al judeţului Caraş-severin, 37-49.

\section{Țeicu, D. 1998}

Banatul Montan în Evul Mediu, Timișoara: Editura Banatica.

\section{Țeicu, D. 2007}

Geografia ecleziastică a Banatului medieval, Cluj-Napoca: Presa Universitară Clujeană.

Țeicu, D. 2009

Cetăți medievale din Banat, Timișoara: Editura Muzeul Banatului Montan.

Țeicu, D. 2009a

Arta minoră medievală din Banat, Timișoara: Editura Cosmopolitan- Art.

\section{Vasile, M. 2004}

Bijuterii antice de la Tibiscum, Jupa, Arheovest 1: $1-7$.

\section{Zwierlein- Diehl, E. 2014}

Magical gems in the medieval and early- modern periods. Tradition, Transformation, Innovation, V. Dasen, J.- M. Spieser (eds.), Les savoirs magiques et leur transmission de 1'Antiquité ä la Renaissance, Micrologus' Library, 60, Firenze: SISMEL, 87-130. 


\section{REZIME \\ EKSPLOATACIJA I PONOVNO KORIŠĆENJE RIMSKIH RUŠEVINA IZ TIBISKUMA, OD SREDNJEG VEKA DO SAVREMENOG DOBA}

KLJUČNE REČI: DACIA, TIBISCUM, RIMSKE SPOLIJE, SREDNJI VEK, SAVREMENO DOBA, SPOMENICI, NAKIT.

Važno pitanje koje smo pokušali da pokrenemo u ovom radu jeste ponovno korišćenje spomenika, građevinskog materijala i drugih objekata iz rimskog perioda pronađenih u Tibiskumu, počev od perioda srednjeg veka pa do savremenog doba. Mesta gde su takvi nalazi otkriveni nalaze se blizu ovog rimskog lokaliteta, u Župi, Kavaranu - Konstantin Daikovičiju, Karansebešu, Turnu Rujeniju, a moguće i u Karbunariju - Ciganeštiju i Obreži. Uopšteno gledano, materijali koji su se ponovo upotrebljavali obuhvataju građevinski materijal, kamen, ciglu, a posebno fragmentovane ili cele spomenike; mali, dragoceni predmeti kao što su antičke geme takođe su bivali ponovo upotrebljeni, tako što su postavljani na srednjovekovno prstenje. Velika većina ovakvih spolija bila je ponovo upotrebljena za gradnju ili obnavljanje srednjovekovnih crkvi, glavne kule $\mathrm{u}$ Turnu Rujeniju ili srednjovekovne tvrđave u Karansebešu. Pljačkanje Tibiskuma je počelo, zasigurno, od XIV veka i nastavilo se tokom sledećeg, sudeći po politici mađarske kraljevske porodice da se grade nova mesta za bogosluženje i popravljaju kraljevske tvrđave zbog opasnosti od turskog prodora.

U savremeno doba, rimski spomenici su korišćeni za ulepšavanje kuća stanovnika Karasebeša ili imanja koje je pripadalo plemićkoj porodici Kapra, u Župi. Budući da se danas, srećom, nalazi u arheološkom rezervatu u Župi, Tibiscum je vrlo pažljivo iskopan i istražen. Ipak, mnogi predmeti koji su bili iskopani u Tibiskumu $\mathrm{u}$ periodu pre nego što je oformljen rezervat ostaju izgubljeni, dok mnogi od spomenika koji su bili pokradeni iz ovog važnog rimskog grada i ugrađeni u zidove modernih zgrada danas više ne postoje.

Arheologija i prirodne nauke (Archaeology and Science) is an Open Access Journal. All articles can be downloaded free of charge and used in accordance with the licence Creative Commons - Attribution-NonCommercial-NoDerivs 3.0 Serbia (https://creativecommons.org/licenses/ by-nc-nd/3.0/rs/.

Časopis Arheologija i prirodne nauke je dostupan u režimu otvorenog pristupa. Članci objavljeni u časopisu mogu se besplatno preuzeti sa sajta i koristiti u skladu sa licencom Creative Commons - Autorstvo-Nekomercijalno-Bez prerada 3.0 Srbija (https://creativecommons.org/ licenses/by-nc-nd/3.0/rs/. 


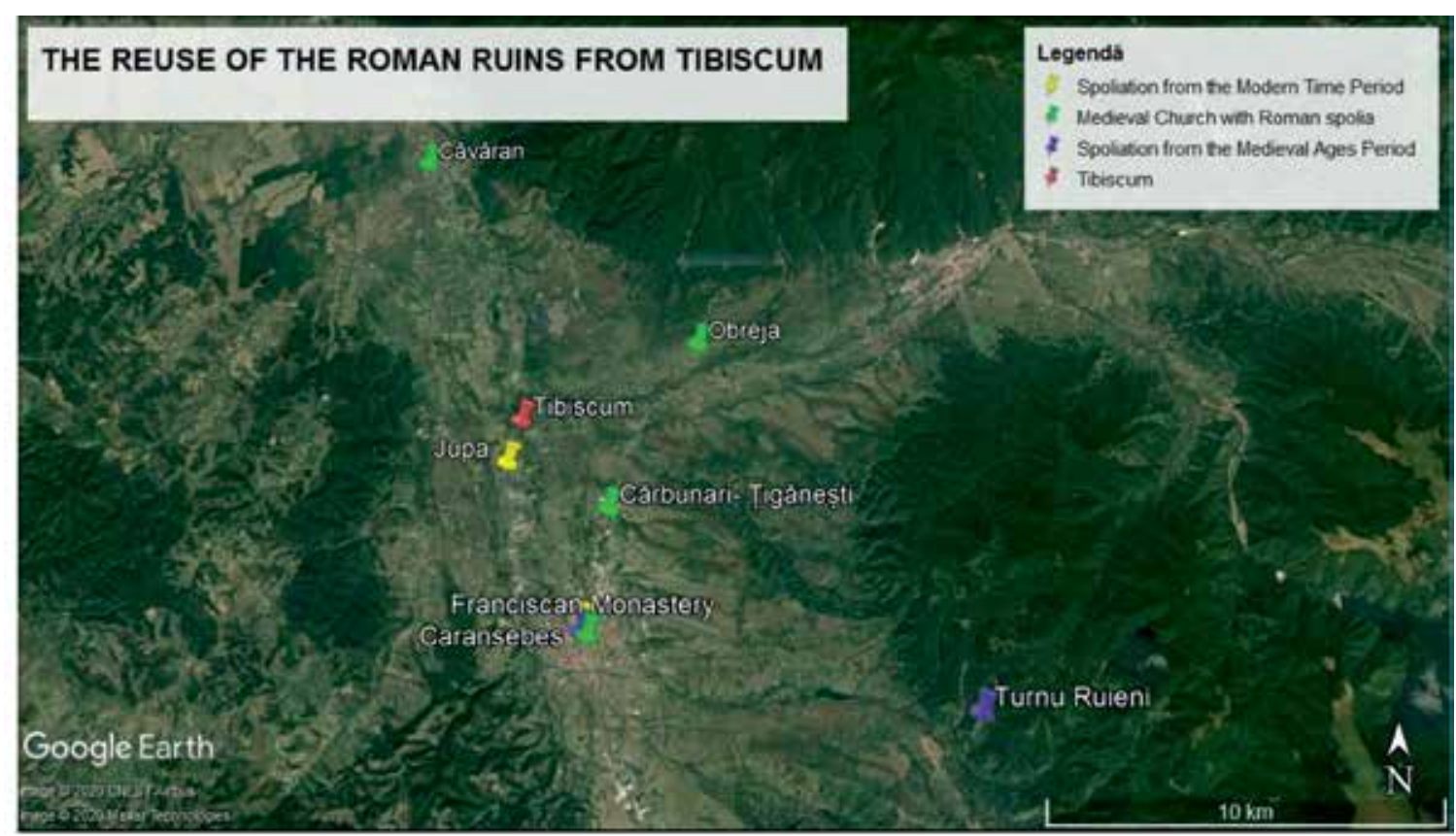

1

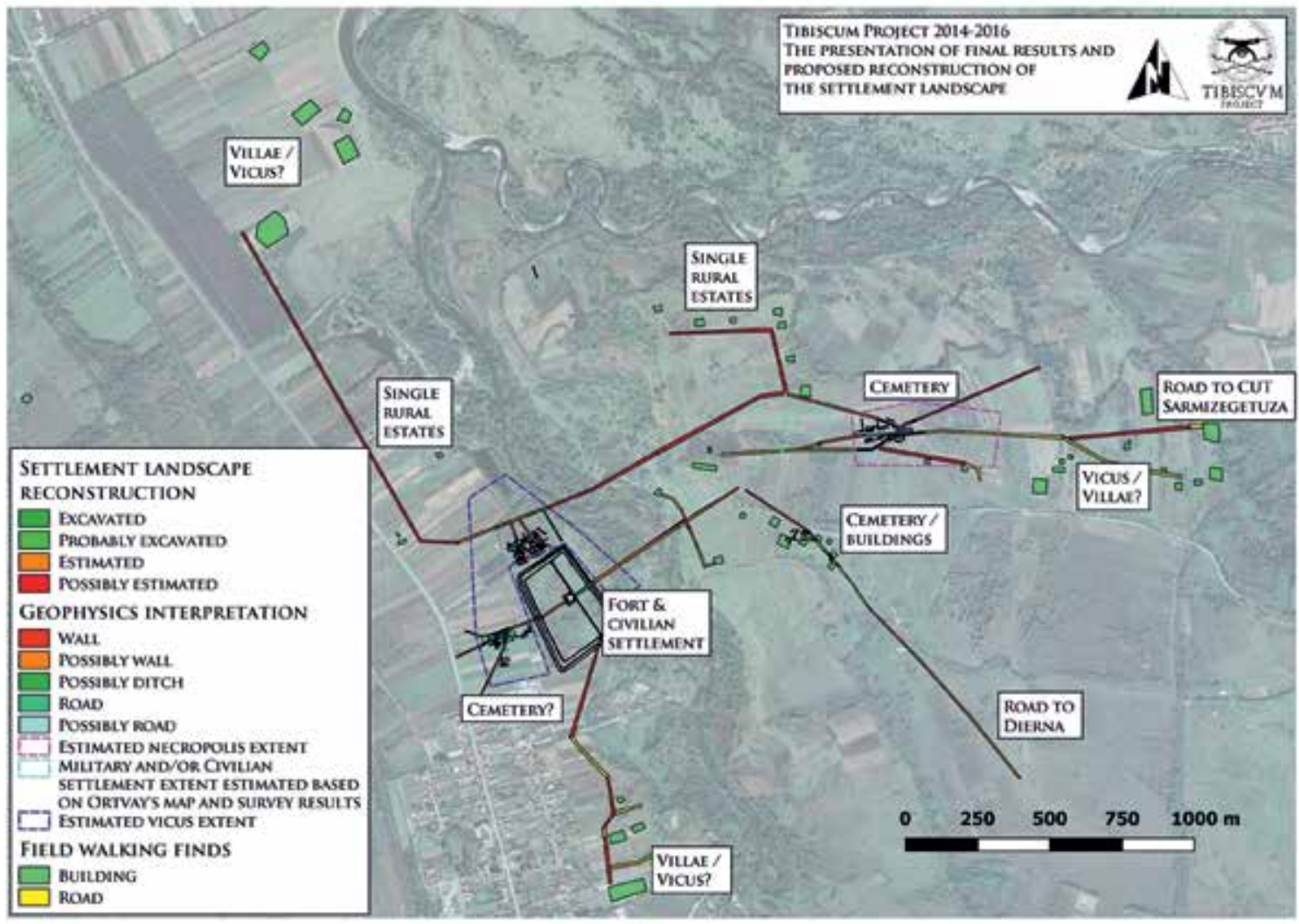

2

I/1 Map with the reuse of roman ruins from Tibiscum in Medieval and Modern ages. I/2 Roman ruins from Tibiscum, after Pisz et al 2020, fig. 12. 

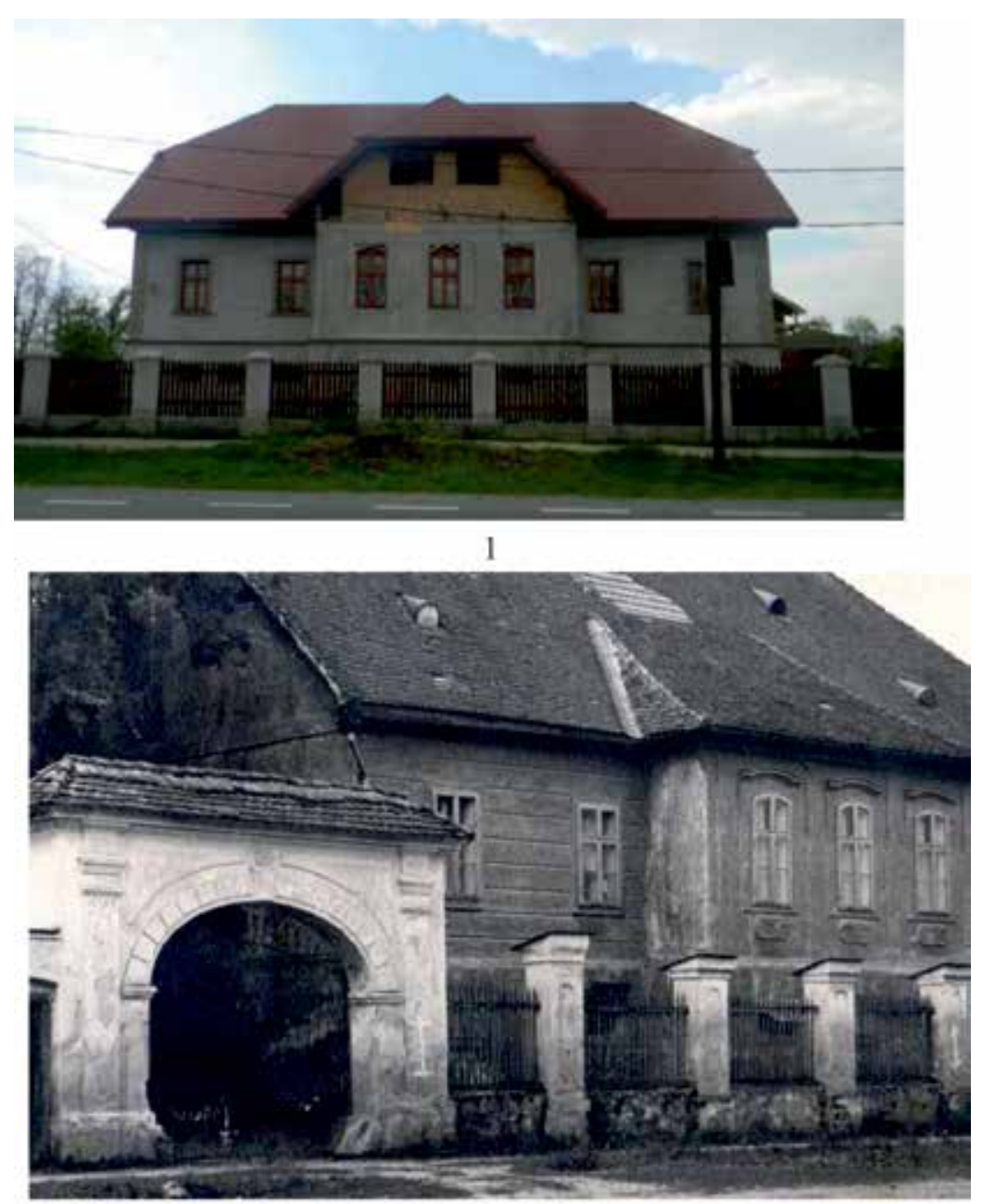

2

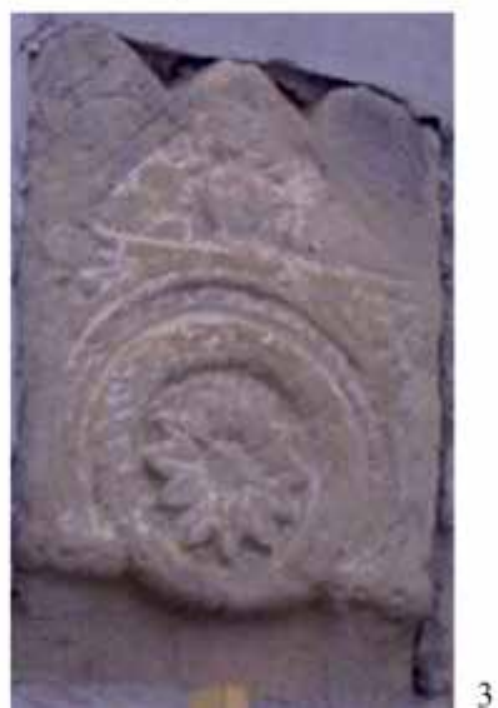

II/1 Capra manor today, after https://adevarul.ro/locale/resita/foto-video-conacele-boieresti-caras-severin-glorie-ruina1_51776e1b053c7dd83f3ee330/index.html.

II/2 Capra Manor at the begining of the XXth century,

after https://adevarul.ro/locale/resita/conacul-capra-vremurile-glorie-7_517a105a053c7dd83f4a33ec/index.html.

II/ 3 Capra Manor, roman stela reused, after Balaci- Crânguș 2013, fig.1. 


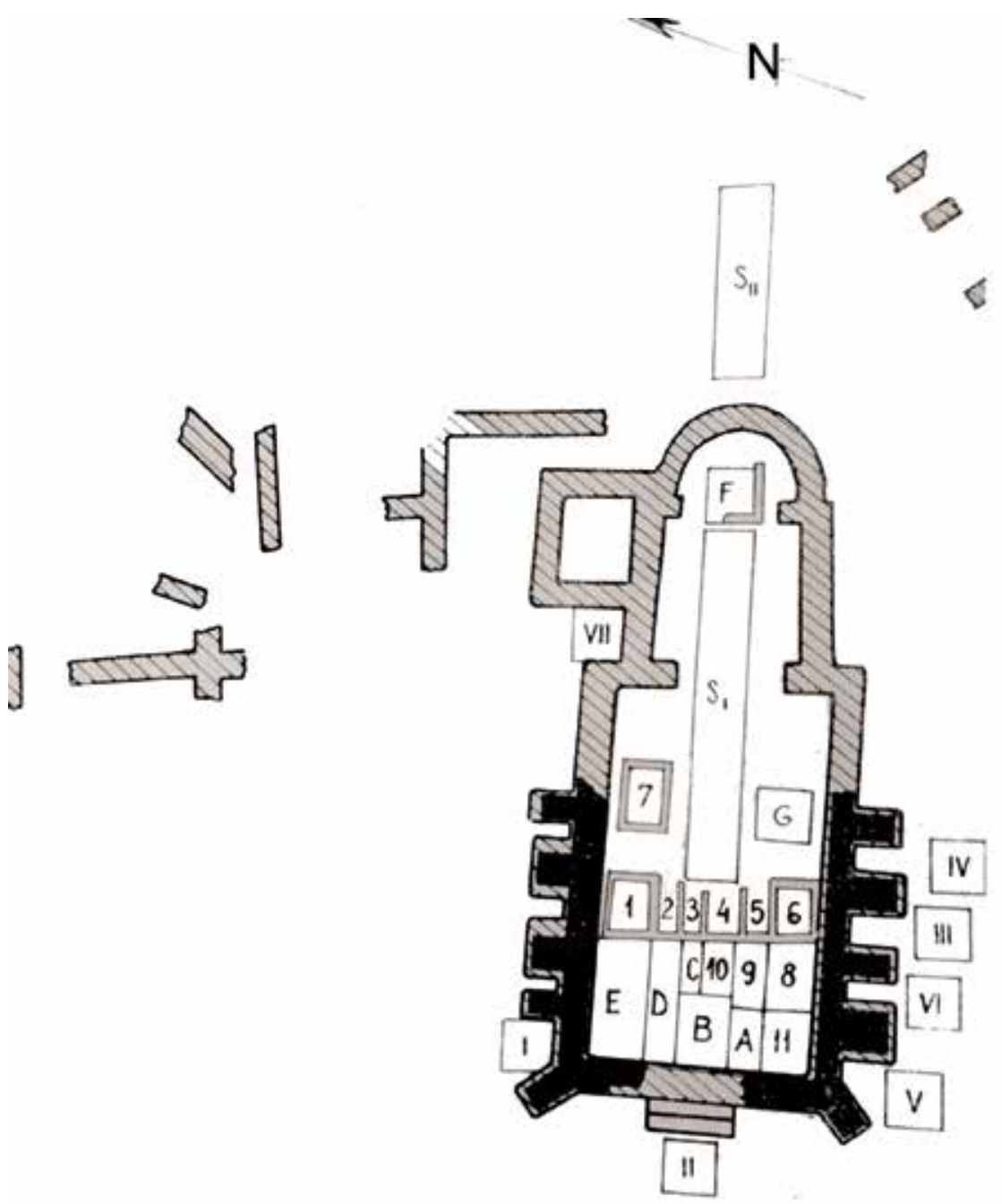

1

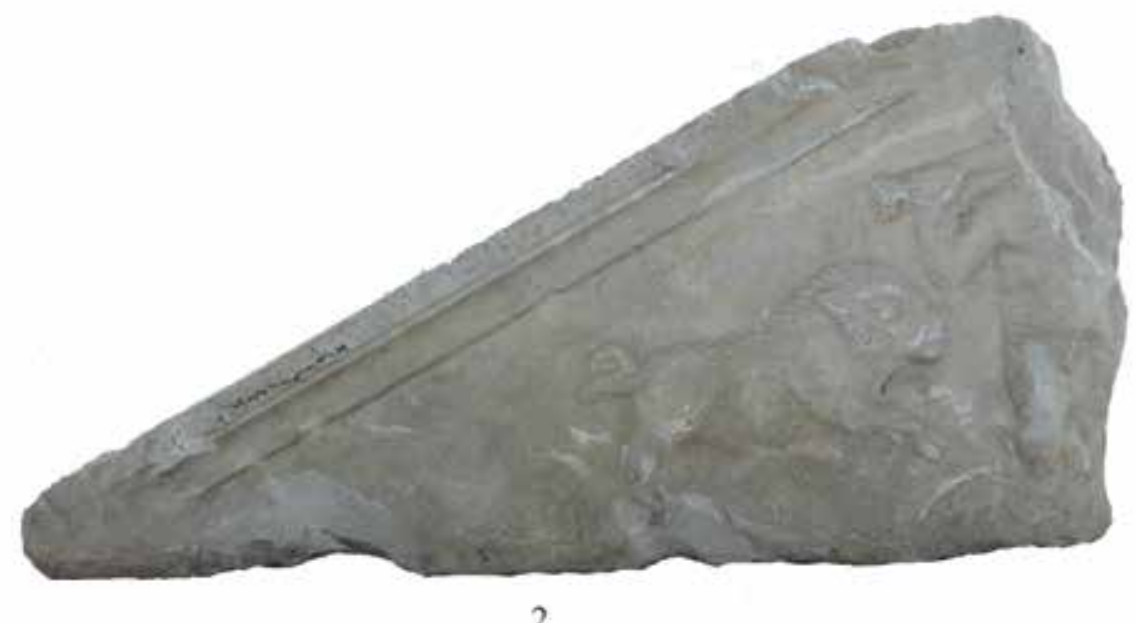

III/1 Medieval church of the Franciscan monastery from Caransebeș, after Bona 1993, pl.3.

III/2 Roman monument discovered in the medieval church of Franciscan monastery from Caransebeș, personal photo. 

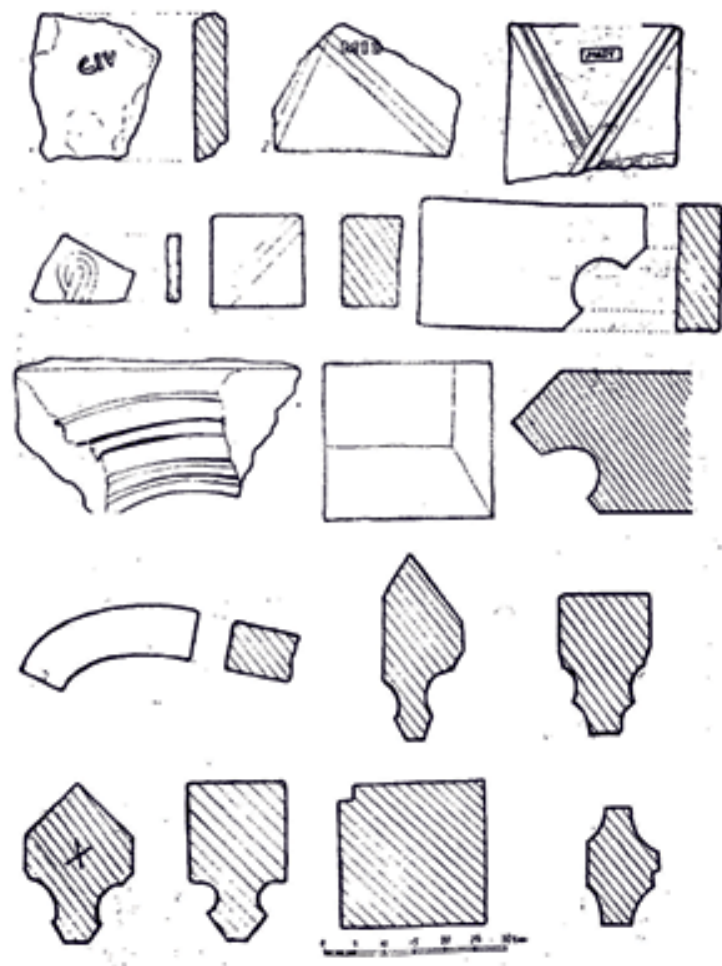

1
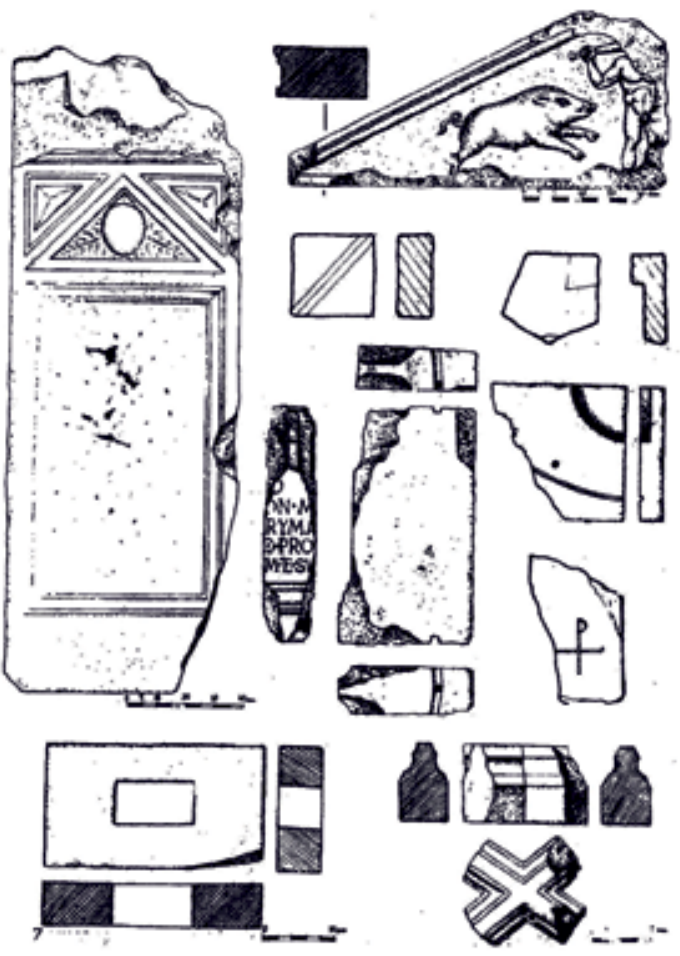

2

IV/1 Roman tegular materials discovered in the medieval church of Franciscan monastery from Caransebeș, after Bona 1993, pl. 5.

IV/2 Roman monuments discovered in the medieval church of Franciscan monastery from Caransebeș, after Bona 1993, pl. 6. 


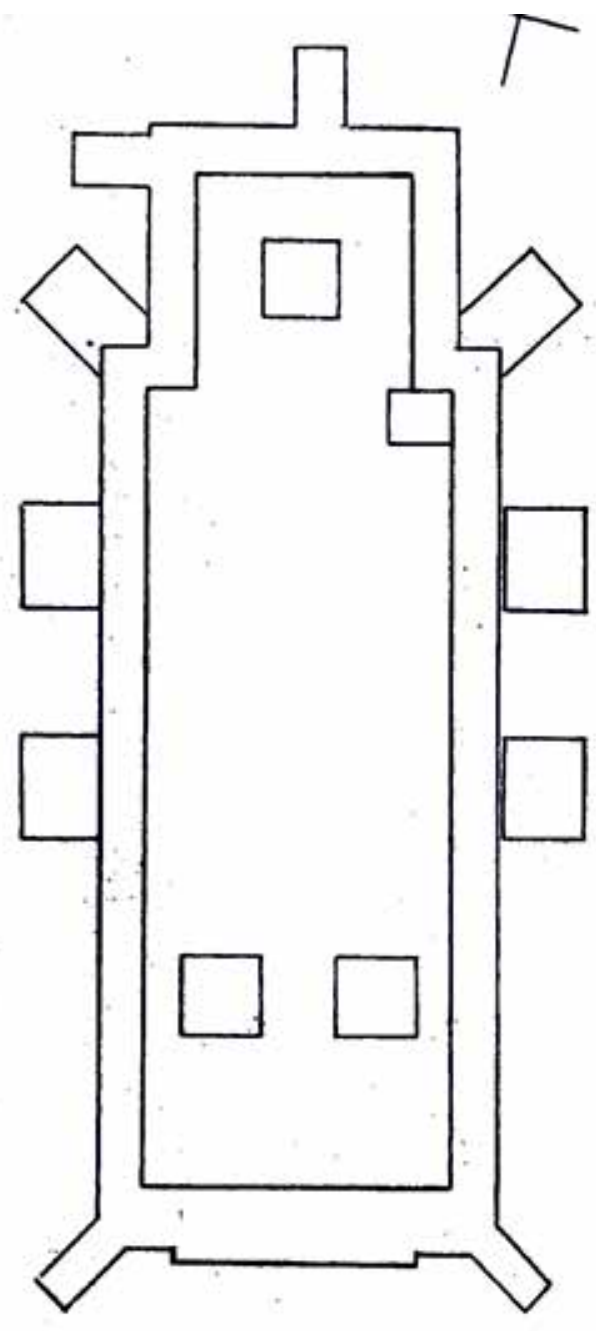

1

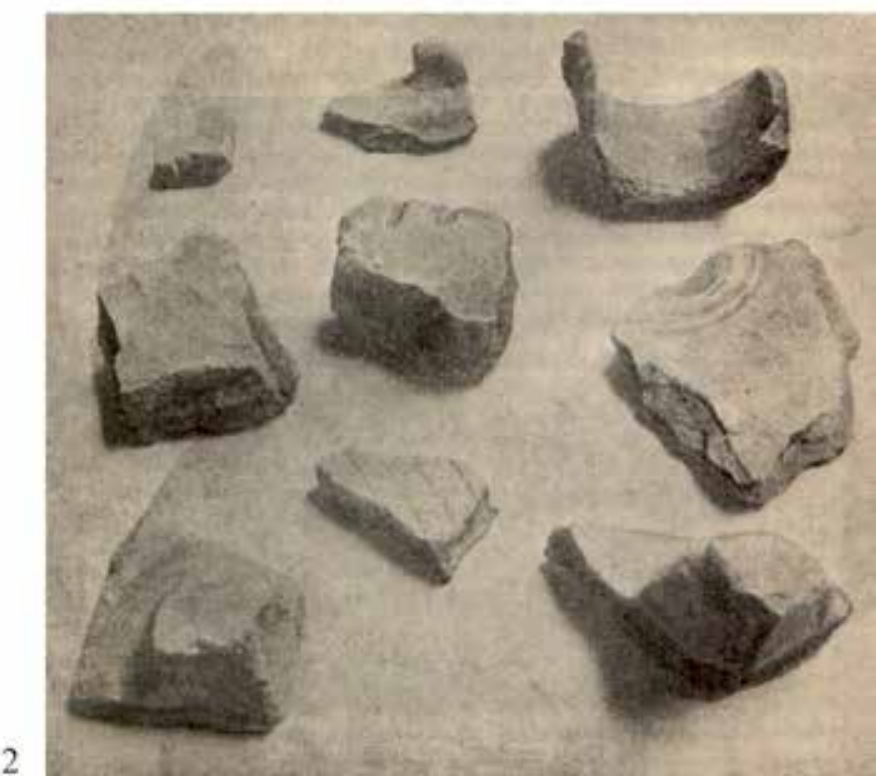

V/1 Medieval church from Căvăran/ Ct. Daicoviciu, after Miloia 1930, 32.

V/2 Roman tegular materials discovered at the medieval church from Căvăran/ Ct. Daicoviciu, after Miloia 1930, 37. 

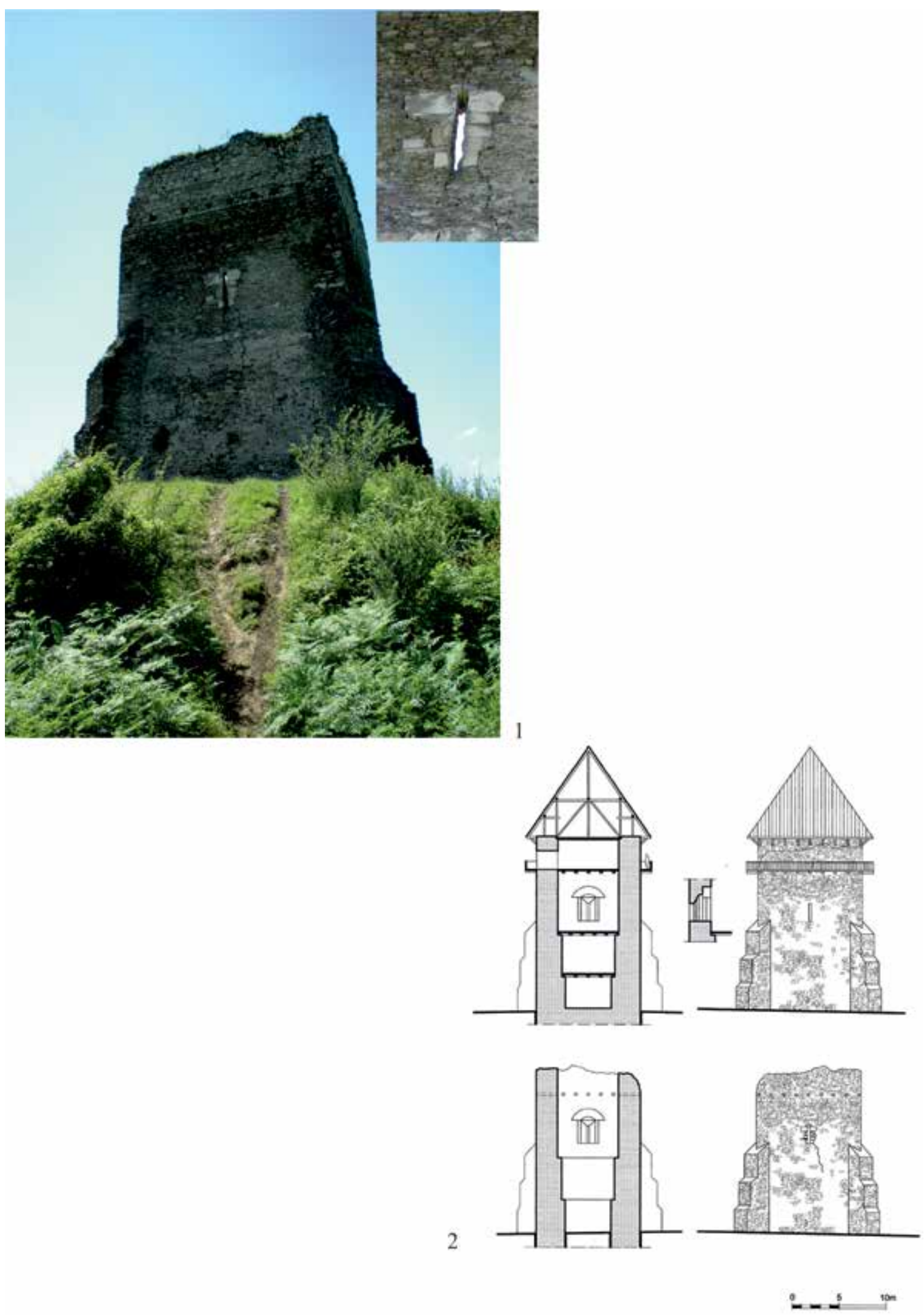

VI/1 The keep from Turnu Ruieni with a detail of roman spolia, personal photo. VI/2 The keep from Turnu Ruieni, after Teicu 2009, pl.16. 

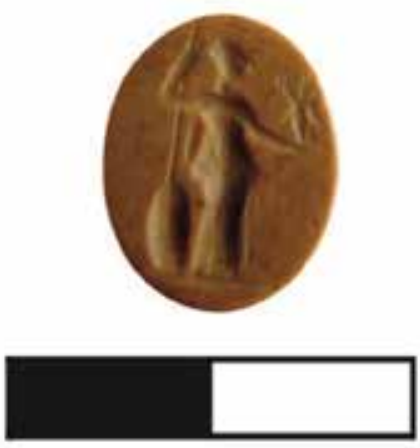

1
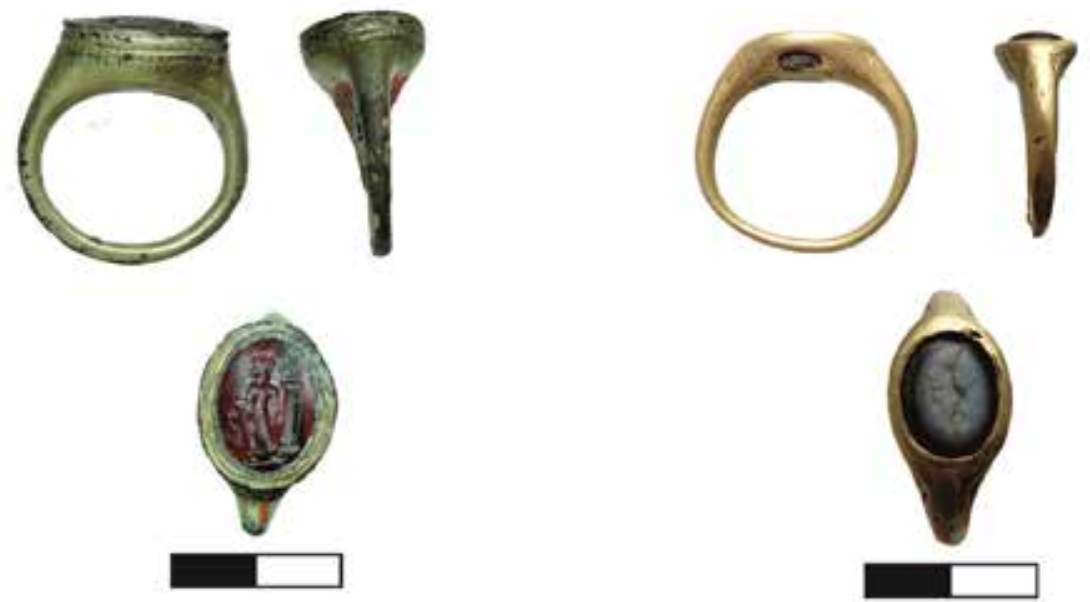

2

3
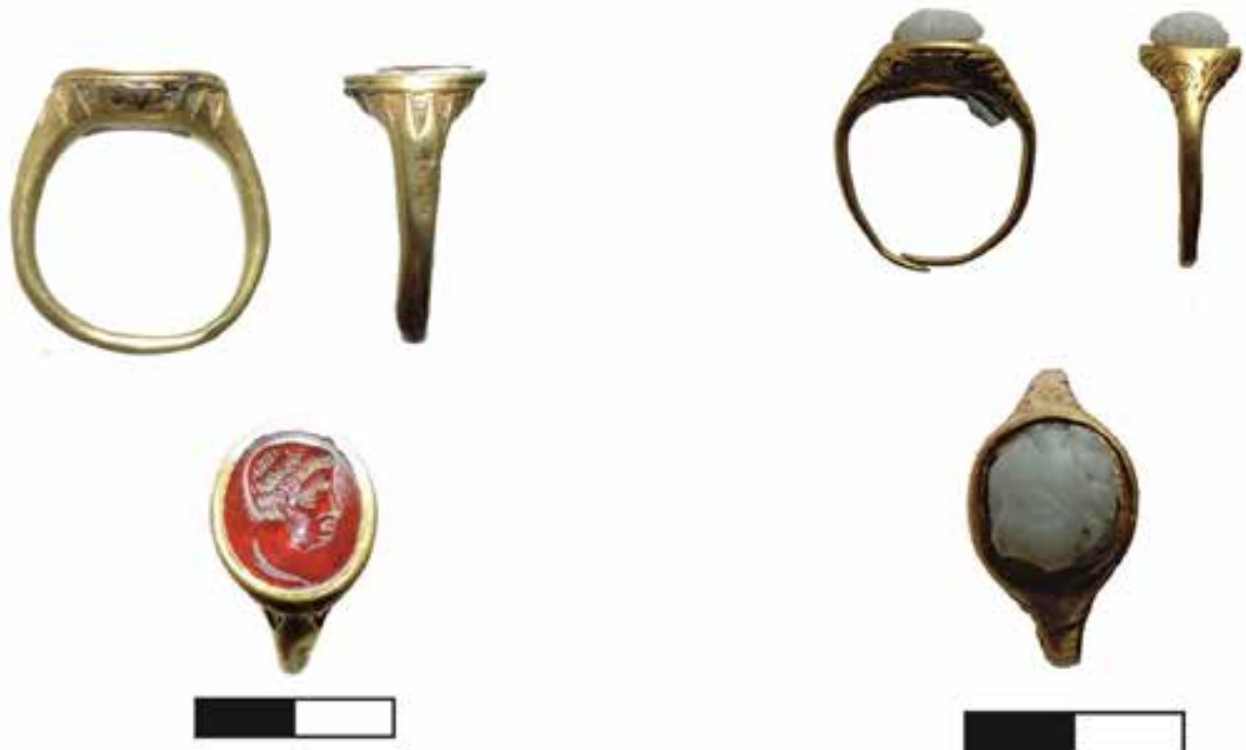

4

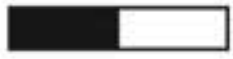

5

VII/1 Roman gem discovered at the medieval church from Obreja, personal photo.

$\mathrm{VII} / 2,3,4,5$ Roman gems and cameos discovered at the medieval church from Caransebeș, personal photo. 